\title{
STATE OF THE LANDSCAPE AND DYNAMICS OF LOSS AND FRAGMENTATION OF FOREST CRITICALLY ENDANGERED IN THE TROPICAL ANDES HOTSPOT: IMPLICATIONS FOR CONSERVATION PLANNING
}

\author{
JAMES RODRÍGUEZ-ECHEVERRY*AND MARGARETH LEITON
}

\begin{abstract}
Departamento de Ecología de Paisaje, Restauración y Conservación de la Biodiversidad. Fundación Takiyaco. Cra 92 No. 2 C-30 Cali, Colombia.

*Corresponding author email: wairajames@yahoo.com
\end{abstract}

Received: $12^{\text {th }}$ February 2021, Accepted: $7^{\text {th }}$ April 2021

\begin{abstract}
Currently, there is no precise information on the degree of transformation of Tropical Andes hotspot landscape and native ecosystems due to the intensification of agricultural and urban land-use. Proper knowledge of these changes would provide crucial information for planning conservation strategies. We evaluated the impact of the intensification of agricultural and urban land-use on the Inter-Andean Dry Forest and Tropical Montane Forest, both of which are categorized as Critically Endangered, and the state of the landscape in the High Rio Guayllabamba watershed, Ecuador, during the periods 1991-2005 and 20052017. The evaluation was carried out using Landsat satellite images of $30 \times 30 \mathrm{~m}$ pixels and landscape metrics. We found an advanced state of landscape transformation. Since the 1990s, the loss of both ecosystems was largely caused by the conversion of forest to agriculture, resulting in substantial changes in the spatial configuration of these ecosystems. From 1991 to $2017,19.8 \%$ and $16.1 \%$ of Inter-Andean Dry Forest and Tropical Montane Forest respectively, were converted to agriculture. The loss of Inter-Andean Dry Forest was $28 \%$ and the number of forest patches increased by more than $150 \%$. The loss of Tropical Montane Forest was $16.5 \%$ and the number of forest patches increased by more than $300 \%$. The largest loss and fragmentation of forest cover occurred from 1991 to 2005 . We suggested planning landscape-scale conservation, using the patch-corridor-matrix model. This model is appropriate given the current configuration of the landscape studied, with Inter-Andean Dry Forest and Tropical Montane Forest restricted to small patches sparsely distributed across the landscape.
\end{abstract}

Keywords: Changing landscape; Ecuador; Forest habitat; Forest landscape; Landscape-scale conservation; Rio Guayllabamba watershed.

\section{INTRODUCTION}

The intensification of agricultural and urban land-use can lead to habitat loss and fragmentation, and these are two of the greatest threats to forest landscapes (Tapia-Armijos et al., 2015; Ferrer-Paris et al., 2018; Rodríguez-Echeverry et al., 2018a). Agricultural and urban land-use modifies the spatial patterns (composition and spatial configuration) of forest 
Rodríguez-Echeverry J., Leiton M.: State of the landscape and dynamics of loss and fragmentation of forest critically endangered in the tropical andes hotspot: Implications for conservation planning

landscapes, such as the total area of forest, patch number, and connectivity (Echeverría et al., 2014; Lindenmayer, 2016). Habitat loss and fragmentation may have negative effects on biodiversity, by increasing isolation of habitats, endangering species, and modifying species' population dynamics (Rodríguez-Echeverry et al., 2015). Such alteration could lead to local and global extinction of the most vulnerable species (Bennett, 2003; Lindenmayer \& Fischer, 2006).

The altered forested landscapes can be a region with a low rate of deforestation and good connectivity (Echeverría et al., 2012) to highly fragmented and modified landscapes. With the progressive forest loss/fragmentation the forest cover represents a reduced area consisting of scattered and isolated habitat patches, with no connectivity (Rodríguez-Echeverry et al., 2018a). Therefore, the evaluation of forest landscape changes allows a better understanding of their degree of integrity, functionality, and landscape characteristics (composition and spatial configuration) (Rodríguez-Echeverry et al., 2017). This evaluation is essential in landscapes with high species diversity and endemism combined with high forest habitat loss (Lindenmayer \& Franklin, 2002; Rodríguez-Echeverry et al., 2015).

The biodiversity hotspots are regions with a global priority for conservation due to their high degree of endemism and strong anthropic impact (Myers et al., 2000). These regions have at least 1,500 species of endemic plants and have lost at least $70 \%$ of their original extent (Mittermeier et al., 2011). The Tropical Andes is a hotspot characterized by being the most diverse for holding the highest plant endemism in the world. The Tropical Andes hosts a total of 30,000 species of native plants, of which $50 \%$ are endemic (NatureServe \& EcoDecision, 2015). The Tropical Dry Forest and Tropical Montane Forest ecosystem, both of which are categorized as Critically Endangered by The International Union for Conservation of Nature (IUCN) (Ferrer-Paris et al., 2018), are a part of the Tropical Andes hotspot. In Ecuador the Tropical Dry Forest is restricted to the lowlands regions across the inter-Andean valleys and has been described as an Inter-Andean Dry Forest (Aguirre et al., 2006), while the Tropical Montane Forest is restricted to the highland regions and is characterized by evergreen forests, frequently enveloped in clouds and mist (IUCN, 2000).

The Inter-Andean Dry Forest and Tropical Montane Forest are in the High Rio Guayllabamba watershed (HRGW), in northern Ecuador. Despite the high value for the biodiversity conservation of this watershed, a number of anthropogenic processes have been associated with the degradation and loss of Inter-Andean Dry Forest and Tropical Montane Forest, such as intensive agriculture, extraction of firewood, and overexploitation of native species (Aguirre et al., 2006, 2011; Mittermeier et al., 2011; NatureServe \& EcoDecision, 2015). The foregoing impacts on the native forest have been the focus of discussion among environmental entities of government and communities, which have highlighted the need to implement effective conservation strategies for native forest ecosystems (Sarmiento, 1995; Aguirre et al., 2011; Ministerio del Ambiente del Ecuador, 2013; NatureServe \& EcoDecision, 2015).

Although there are few specific studies on the diversity of flora and fauna and their state of conservation in the Inter-Andean Dry Forest and Tropical Montane Forest in the HRGW (Sarmiento, 1995; Aguirre et al., 2006, 2011; Cadena-Ortíz et al., 2015; Cisneros-Heredia et al., 2017), there are no spatio-temporal studies on the transformation state of this landscape, and in particular on the changes in spatial patterns of the native forest ecosystems due to the intensification of agricultural and urban land-use. This type of information is necessary to implement actions or strategies of conservation and restoration at the landscape scale, which offers a way out to the degradation of the ecosystems while ensuring the 
participation of different levels of governance and the community in this process (Ministerio del Ambiente del Ecuador, 2013).

We assessed the impact of the intensification of agricultural and urban land-use on the spatial pattern of the Inter-Andean Dry Forest and Tropical Montane Forest and the state of the landscape in the HRGW by 1) determining deforestation rates during the periods 19912005 and 2005-2017,2) evaluating the changes in the spatial patterns of forest cover over time and 3) determining the state of transformation of the landscape. We hypothesize that there has been a substantial loss of Inter-Andean Dry Forest and Tropical Montane Forest due to an increase in agriculture and urban areas, resulting in an advanced state of a transformed landscape. This study is the first of its kind undertaken to understand the spatio-temporal changes in the Inter-Andean Dry Forest and Tropical Montane Forest, which can contribute to the conservation planning of these threatened ecosystems.

\section{MATERIAL AND METHODS}

\section{Study area}

The study area is the HRGW located in the cordillera of the Andes $\left(0^{\circ} 13^{\prime} \mathrm{N}\right.$ and $\left.0^{\circ} 40^{\prime} \mathrm{S}\right)$ in the provinces of Pichincha and Imbabura, Ecuador (Fig. 1). The watershed occupies 6,758 $\mathrm{Km}^{2}$, has a mean temperature of $14^{\circ} \mathrm{C}$ and an annual rainfall of $1,200 \mathrm{~mm}$. The HRGW is a topographically diverse area where the elevation ranges from 1,150 to 5,897 $\mathrm{m}$ a.s.l. (Instituto Nacional de Meteorología e Hidrología, 2005). Currently, the total area of watershed consists of agriculture $43 \%$, Montane Forest $19 \%$, Paramo $17 \%$, shrub vegetation $10 \%$, Inter-Andean Dry Forest $5 \%$, urban areas $4 \%$ and other land-uses types (water bodies, bare land, and snow) $2 \%$. The watershed has a human population of approximately $3,228,233$ inhabitants, with a population density of 591 people $\mathrm{km}^{-2}$. The main economic activity in the watershed is agriculture (Sistema Nacional de Información, 2019).

Fig. 1: Location of the HRGW in the provinces of Pichincha and Imbabura, Ecuador
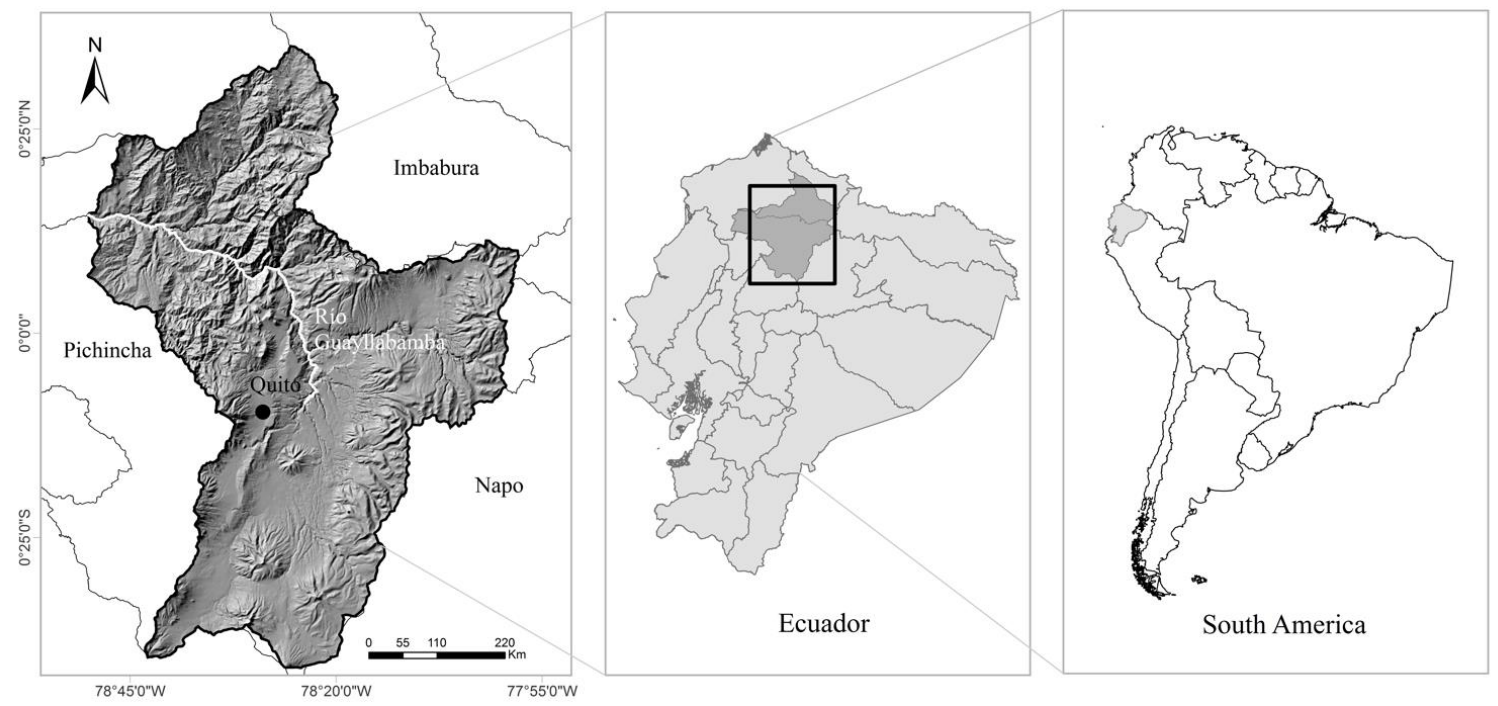
Rodríguez-Echeverry J., Leiton M.: State of the landscape and dynamics of loss and fragmentation of forest critically endangered in the tropical andes hotspot: Implications for conservation planning

The Inter-Andean Dry Forest ecosystem, located in the study area, occupies 33,609 ha and covering from 1,400 to 2,500 m a.s.l. (Ministerio del Ambiente del Ecuador, 2013). This ecosystem is characterized by the lowland forests, with open canopies and shrubs up to $2 \mathrm{~m}$ growing on dry mountain slopes. The vegetation composed of Acacia macracantha, Caesalpinia spinosa, Opuntia cylindrica, Opuntia soederstromiana, Croton wagneri and Dalea hufusa (Aguirre et al., 2011). The fauna is represented by Stenocercus guentheri and the Lampropeltis triangulum micropholis reptiles, the Camptostoma obsoletum and Catamenia analis birds, and the Lycalopex culpaeus mammal (MECN, 2009). The Tropical Montane Forest occupies 130,557 ha and covering from 3,000 to 3,400 m a.s.l. (Ministerio del Ambiente del Ecuador, 2013). In this ecosystem, tree trunks, branches, and rock surfaces are covered with moss, ferns, orchids, and other epiphytic plants (IUCN, 2000). The vegetation comprises of Clusia alata, Blackea quadriflora, Meriania tomentosa, Meriania maxima, and Cecropia maxima. The fauna is represented by Anoura geoffroyi bat, the Riama colomaromani lizard, the Diglossa lafresnayii bird, the Prisitmantis eugeniae amphibian, and the Thomasomys aureus rodent (MECN, 2009).

\section{Land-cover classification}

Landsat satellite images were used to generate the land-use thematic maps for 1991 (TM), 2005 (ETM), and for 2017 (ETM) (<5\% cloud cover). These images were acquired for the months of July 1991 and 2005, and October 2017, from the USGS portal. Due to a prevailing cloud cover in the Andes range, it was impossible to obtain images with cloudiness $<10 \%$ for the same month in the three years of study. To avoid major differences in phenology, all images acquired were taken during the dry season (image dates from June to November). As fluctuations in precipitation are relevant for the spectral response of biomass, all selected images represent similar drought conditions. The images used had a spatial resolution of $30 \mathrm{x}$ $30 \mathrm{~m}$ pixels, which is a resolution appropriate for the spatial analysis (Daly, 2006). The images were corrected geometrically, atmospherically, and topographically (Chander et al., 2009). The geometric correction was performed using the "full processing" module in PCI Geomatics and ENVI. This consisted of the transformation of each image using GCPs (ground control points) and a 2nd order polynomial mathematical model. The satellite images were georeferenced separately by locating approximately 120 GCPs in each image and producing corresponding reference maps. The geometric accuracy ranged from 0.11 to 0.29 pixels, corresponding to $3.3-8.7 \mathrm{~m}$. Atmospheric correction was applied to all of the scenes, transforming the original radiance image to a reflectance image. The topographic correction was made using the IDRISI Andes hillshade control procedure (IDRISI, 2012) with a Digital elevation model $(30 \times 30 \mathrm{~m})$ to remove differences in solar illumination influenced by relief. Through the $\mathrm{C}$ factor method, the topographic shadows were eliminated (Reese \& Olsson, 2011). The Normalized Difference Vegetation Index (NDVI), Simple Ratio Index (SR), Soil Adjusted Vegetation Index (SAVI), and Land Surface Water Index (LSWI) were used to increase the accuracy of the classification (Huete, 1988). Supervised classification was carried out using the statistical method of maximum likelihood estimation and 950 training points taken in the field, which represented the patterns of the types of land cover. The accuracy in the classification of the images was calculated using confusion matrices from 540 validation points taken in the field. For the accuracy of 1991 and 2005 images, land cover maps generated by previous studies were used (Sistema Nacional de Información, 2019). For the three thematic maps, the following categories were identified: Inter-Andean Dry Forest, Tropical Montane Forest, Paramo, shrub vegetation, agriculture, urban areas, bare land, snow, and water bodies. 


\section{Analysis of changes in the spatial patterns}

We assessed the impact of land-use change and intensification of agricultural and urban land-use on the spatial pattern of Inter-Andean Dry Forest and Tropical Montane Forest by determining the changes of area, patch edge, core area, aggregation, shape, contrast, and proximity metrics (Table 1).

Table 1: Landscape metrics used for the analysis of spatial patterns of the Inter-Andean Dry Forest and Tropical Montane Forest in the HRGW (McGarigal et al., 2013

\begin{tabular}{|c|c|c|c|}
\hline Metrics & Description & $\begin{array}{l}\text { Unit of } \\
\text { measurement }\end{array}$ & Variation Rate \\
\hline Total area & $\begin{array}{l}\text { It is the sum of all patches' } \\
\text { areas of the same forest type }\end{array}$ & Hectares & $\mathrm{CA}>0$, unlimited. \\
\hline Patch area & $\begin{array}{l}\text { Area of each patch of native } \\
\text { forest in the landscape }\end{array}$ & Hectares & 0 and unlimited \\
\hline $\begin{array}{l}\text { Metric of the largest } \\
\text { patch }\end{array}$ & $\begin{array}{l}\text { Percentage of the area of the } \\
\text { largest native forest patch with } \\
\text { respect to the total landscape } \\
\text { area }\end{array}$ & Percentage & $0<\mathrm{LPI} \leq 100$ \\
\hline Total edge length & $\begin{array}{l}\text { It is equal to the sum of the } \\
\text { lengths }(\mathrm{km}) \text { of all edge } \\
\text { segments that involve the } \\
\text { corresponding patch type }\end{array}$ & Kilometers & $\mathrm{TE} \geq 0$, unlimited. \\
\hline Average Core Area & $\begin{array}{l}\text { The core area of the native } \\
\text { forest, specified by the depth of } \\
\text { edge according to the } \\
\text { proximity of the patch to other } \\
\text { land uses }\end{array}$ & Hectares & $\begin{array}{l}\text { CORE } \geq 0 \text { and } \\
\text { unlimited }\end{array}$ \\
\hline Number of Patches & $\begin{array}{l}\text { Number of patches in the } \\
\text { landscape }\end{array}$ & None & $\mathrm{NP} \geq 1$, unlimited \\
\hline $\begin{array}{l}\text { Average } \\
\text { perimeter-area ratio }\end{array}$ & $\begin{array}{l}\text { Relationship between the } \\
\text { perimeter and the area }\end{array}$ & None & $\begin{array}{l}\text { PARA }>0 \text { and } \\
\text { unlimited }\end{array}$ \\
\hline $\begin{array}{l}\text { Average edge contrast } \\
\text { weighted by area }\end{array}$ & $\begin{array}{l}\text { Degree of the contrast of the } \\
\text { forest with respect to its } \\
\text { density. The contrast represents } \\
\text { the magnitude of the difference } \\
\text { between the forest and other } \\
\text { land uses }\end{array}$ & Percentage & $0 \leq \mathrm{ECON} \leq 100$ \\
\hline $\begin{array}{l}\text { Average distance to the } \\
\text { nearest neighbor }\end{array}$ & $\begin{array}{l}\text { The proximity of native forest } \\
\text { patches, based on the weighted } \\
\text { average distance }\end{array}$ & Meters & $\begin{array}{l}\text { ENN }>0 \text { and } \\
\text { unlimited }\end{array}$ \\
\hline Aggregation Index & $\begin{array}{l}\text { The number of like adjacencies } \\
\text { involving the native forest }\end{array}$ & Percentage & $0 \leqq \mathrm{AI} \leqq 100$ \\
\hline
\end{tabular}


The choice of the metrics used was based on the review of studies on landscape metrics that were representative of essential components of the landscape structure, such as the quality of the patches, the edge of the patch, the context of the patch in the landscape, and patch connectivity (Peng et al., 2010; Rodríguez-Echeverry et al., 2018b). The analysis of these metrics was carried out using FRAGSTATS (McGarigal et al., 2013) and the Spatial Analyst extension for ArcGIS 10.4 (ESRI, 2016).

To calculate the edge contrast metric, contrast weights were assigned between the patches edges of the Inter-Andean Dry Forest, Tropical Montane Forest, and other types of land-use in the study area. The contrast weight of the edges was determined based on the variables of composition and structure of the vegetation. These variables were measured in 30 sampling plots of $20 \times 10 \mathrm{~m}$, which were established within forest patches. To calculate the core area, perpendicular distances from the edge to the center of the patch were used. These distances corresponded to the edge effect area between the forest and other types of land-use. The distances assigned were based on those reported in the works carried out by Laurance et al. (2002), López-Barrera (2004), and Lindenmayer \& Fischer (2006), considering that the degree of contrast between habitats (soft or abrupt edges) expresses the magnitude and distance of primary and secondary responses of the structure, and the habitat's composition and processes before the edge effects.

The analysis of the transition from Inter-Andean Dry Forest cover and Tropical Montane Forest cover to other land-uses was carried out using Land Change Modeler for Ecological Sustainability extension of IDRISI Andes (IDRISI, 2012). The annual rate of change for forests, agriculture, and urban areas was analyzed using the following formula:

$$
P=\left[\left(\frac{A_{2}}{A_{1}}\right)^{\left(\frac{1}{\left(t_{2}-t_{1}\right)}\right)}-1\right] \times 100
$$

$\mathrm{A}_{1}$ and $\mathrm{A}_{2}$ are the class areas at $\mathrm{t}_{1}$ and $\mathrm{t}_{2}$ time, respectively; and $\mathrm{P}$ is the percentage of change per year (Newton, 2007).

We identified land-use change hotspots using the maps of 1991 and 2017. Considering the surface and number of patches of forest, and the surface of other land-use types, we identified the deforestation and fragmentation hotspots that are the areas with the highest changes from forest to other land-use.

\section{Analysis of state of the landscape}

The current state of alteration of the landscape was analyzed based on the landscape change models proposed by McIntyre \& Hobbs (1999) and Echeverría et al. (2012). McIntyre and Hobbs model, which is based on loss and fragmentation of forest habitat, and percentage of remaining forest habitat, proposes four landscape states: intact $(>90 \%$ of remaining habitat), variegated (60-90\%), fragmented (10-60\%), and relictual $(<10 \%)$. A functional distinction between variegated and fragmented landscapes is supported by the percolation theory that indicates that organisms are operationally unfragmented when there is $>60 \%$ habitat retention. Between $10 \%$ and $60 \%$ retention (fragmented landscapes), organisms of medium and low mobility may be highly affected by fragmentation. Below $10 \%$ retention (relictual), organisms may be severely affected by fragmentation; in this state, there appears to be an important difference in the composition of flora and fauna. The Echeverría et al. model proposes three phases of landscape alteration based on dominant 
human processes of the landscape and changes in the matrix over the entire study period. In Phase I, the main transformation process corresponds to forest degradation. The second transformation process is the clearcutting of forests to enable farming or cattle raising. In this phase, the landscape is dominated by degraded forest cover. In Phase II, the clearance for agriculture creates a landscape dominated by disturbed forest and shrubland. In Phase III, the landscape is mostly affected by the habilitation of wooded land rather than by degradation and is dominated by agricultural land or livestock.

\section{RESULTS}

\section{Accuracy of classification}

For the validation of the 2017 land cover map, we used a confusion matrix (Table 2). According to Foody (2002), the overall accuracy shows the percentage of cases correctly allocated. Our results showed an overall accuracy of $93 \%$, which means that the 2017 land cover classification had a high performance in discriminating the pixels with natural cover from those with other covers (non-natural covers). The areas classified as natural cover and other covers were accurate to $95.2 \%$ and $90.7 \%$, respectively.

Table 2: Confusion matrix obtained from the accuracy assessment of the 2017 land cover map of the HRGW

\begin{tabular}{|c|c|c|c|c|c|}
\hline \multirow[b]{2}{*}{ CLASSIFIED } & \multicolumn{3}{|c|}{ REFERENCE } & \multirow[b]{2}{*}{$\begin{array}{c}\text { User's } \\
\text { accuracy }\end{array}$} & \multirow[b]{2}{*}{$\begin{array}{c}\text { Commission } \\
\text { error }\end{array}$} \\
\hline & $\begin{array}{c}\text { Natural } \\
\text { Cover }\end{array}$ & $\begin{array}{c}\text { Other } \\
\text { Covers }\end{array}$ & Total & & \\
\hline Natural Cover & 258 & 13 & 271 & 95.20 & 4.80 \\
\hline Other Covers & 25 & 244 & 269 & 90.70 & 9.30 \\
\hline Total & 283 & 257 & 540 & & \\
\hline Producer's accuracy & 91.17 & 94.94 & & & \\
\hline Omission error & 8.83 & 5.06 & & & \\
\hline Overall accuracy & 0.93 & & & & \\
\hline
\end{tabular}

\section{Change in agricultural and urban land use}

In the study landscape, there was an area increase of $31.5 \%$ of agriculture from 1991 to 2017 (i.e. at annual rates of $1.07 \%$ ). The largest area increase (29.4\%) occurred from 1991 to 2005 , expanded at annual rates of $1.9 \%$ (Fig. 2). There was an area increase of $119.1 \%$ of urban areas from 1991 to 2017 (i.e. at annual rates of 3.06\%). The largest area increase (51.42\%) occurred from 2005 to 2017, expanded at annual rates of $3.5 \%$ (Fig. 2).

\section{Deforestation and fragmentation patterns}

There was a loss of $28 \%$ of Inter-Andean Dry Forest in the study landscape from 1991 to 2017 (i.e. a mean annual loss of $1.3 \%$ ) (Fig. 2). The largest loss (19\%) occurred from 1991 to 2005 (i.e. a mean annual loss of $1.53 \%$ ). The number of patches of Inter-Andean Dry Forest increased by $300 \%$ from 1991 to 2005 but decreased by $42 \%$ in 2017 (Table 3 and Fig. 2). There was a loss of $16.5 \%$ of Tropical Montane Forest from 1991 to 2017 (i.e. a mean annual loss of $0.7 \%$ ) (Fig. 2). The largest loss (11.5\%) occurred from 1991 to 2005 (i.e. a mean annual loss of $0.9 \%$ ). The number of patches of Tropical Montane Forest 
increased by $665 \%$ from 1991 to 2005 but decreased by $27 \%$ in 2017 (Table 3 and Fig. 2). From 1991 to 2017 the major contributions to the net change were the conversion of Inter-Andean Dry Forest to agriculture $(19.8 \%)$ and Tropical Montane Forest to agriculture $(16.1 \%)$ (Fig. 3). The minor contributions to the net change were the conversion Inter-Andean Dry Forest and Tropical Montane Forest to urban areas, $9 \%$ and $0.1 \%$ respectively (Fig. 3). Inter-Andean Dry Forest and Tropical Montane Forest registered a similar trend of deforestation and fragmentation over the entire study period. In 2017 the hotspots of deforestation and fragmentation were located in the north and southeast parts of the Inter-Andean Dry Forest; and in the north, center, and west parts of the Tropical Montane Forest (Fig. 2). Agriculture was the dominant cover in the landscape from 1991 to 2017.

Fig. 2: Spatio-temporal variation and percentage of the area occupied by the types of land cover in 1991, 2005, and 2017 in the HRGW
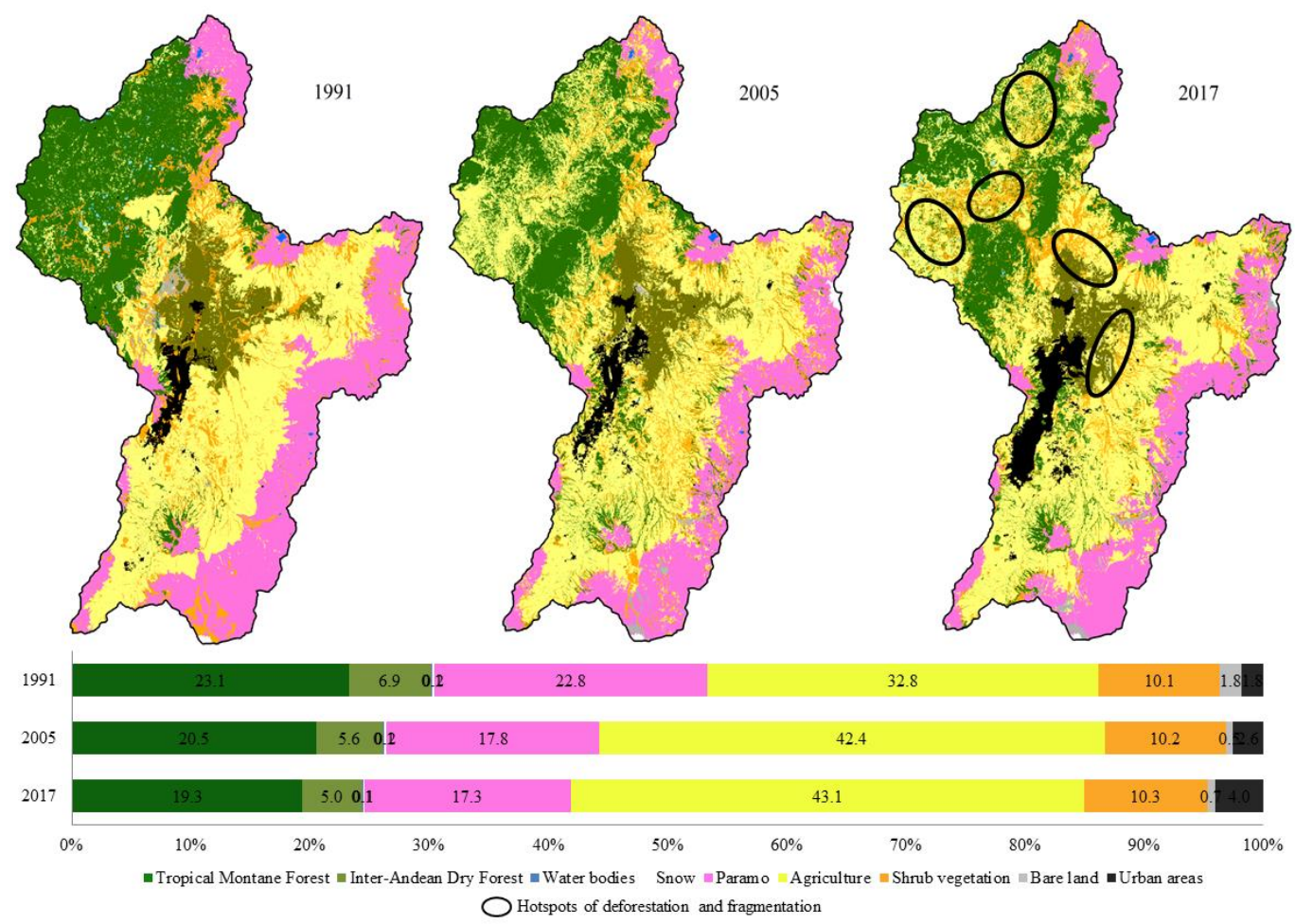
Fig. 3: Major trajectories of land cover change and their contributions to the net change in percentage of the total area of the respective land cover types

1991

2005

2017

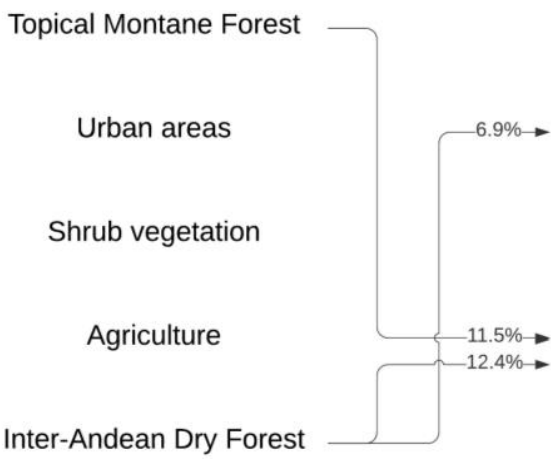

Topical Montane Forest

Urban areas

Shrub vegetation

Agriculture

Inter-Andean Dry Forest

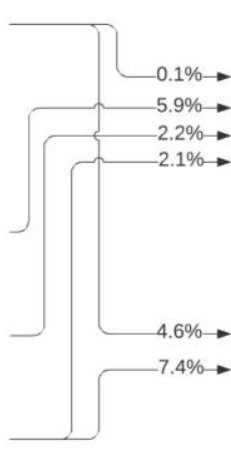

Topical Montane Forest

Urban areas

Shrub vegetation

Agriculture

Inter-Andean Dry Forest

Table 3: Changes in landscape pattern metrics for the Inter-Andean Dry Forest and Tropical Montane Forest in the HRGW between 1991 and 2017

\begin{tabular}{|c|c|c|c|c|c|c|}
\hline & \multicolumn{3}{|c|}{ Inter-Andean Dry Forest } & \multicolumn{3}{|c|}{ Tropical Montane Forest } \\
\hline Landscape metrics & 1991 & 2005 & 2017 & 1991 & 2005 & 2017 \\
\hline Metric of the largest patch (\%) & 6.05 & 4.84 & 4.10 & 20.73 & 8.66 & 4.40 \\
\hline Total Edge $(\mathrm{km})$ & 2,742 & 4,379 & 3,370 & 8,331 & 22,774 & 21,896 \\
\hline Average Core Area (ha) & 0.79 & 0.72 & 0.69 & 0.84 & 0.67 & 0.55 \\
\hline Number of patches & 793 & 2,377 & 1,379 & 3,981 & 26,487 & 19,348 \\
\hline $\begin{array}{c}\text { Average distance to the } \\
\text { nearest neighbor (m) }\end{array}$ & 85 & 203 & 241 & 100 & 163 & 168 \\
\hline Average perimeter-area ratio & 888 & 1,207 & 1,070 & 917 & 1,072 & 1,004 \\
\hline $\begin{array}{l}\text { Average edge contrast } \\
\text { weighted by area (\%) }\end{array}$ & 40.21 & 73.25 & 72.80 & 42.75 & 75.41 & 74.25 \\
\hline Aggregation index (\%) & 95.70 & 92.61 & 91.90 & 96 & 87.60 & 87.49 \\
\hline
\end{tabular}

\section{Changes in the spatial patterns}

In the HRGW considerable changes were found in the distribution of forest patch size from 1991 to 2017 (Fig. 4). In 1991, 88 \% of the Inter-Andean Dry Forest area was concentrated in patches between 10,000 and 50,000 ha; $5 \%$ in patches between 500 and 2,000 ha; and $7 \%$ of the remaining forest area occurred in isolated patches of less than 500 ha (Fig. 4). In 2005, $86 \%$ of the Inter-Andean Dry Forest area was concentrated in patches between 10,000 and 50,000 ha, $8 \%$ in patches between 2,000 and 10,000 ha; and $6 \%$ of the remaining forest area occurred in isolated patches of less than 500 ha. In 2017, $82 \%$ of the Inter-Andean Dry 
Rodríguez-Echeverry J., Leiton M.: State of the landscape and dynamics of loss and fragmentation of forest critically endangered in the tropical andes hotspot: Implications for conservation planning

Forest area occurred in patches between 10,000 and 50,000 ha; $10 \%$ in patches between 2,000 and 10,000 ha; $3 \%$ in patches between 500 and 2,000 ha; and $5 \%$ of the remaining forest area occurred in patches of less than 500 ha (Fig. 4).

Fig. 4: Temporal variation of the patches size of A) Inter-Andean Dry Forest and B) Tropical Montane Forest in the HRGW
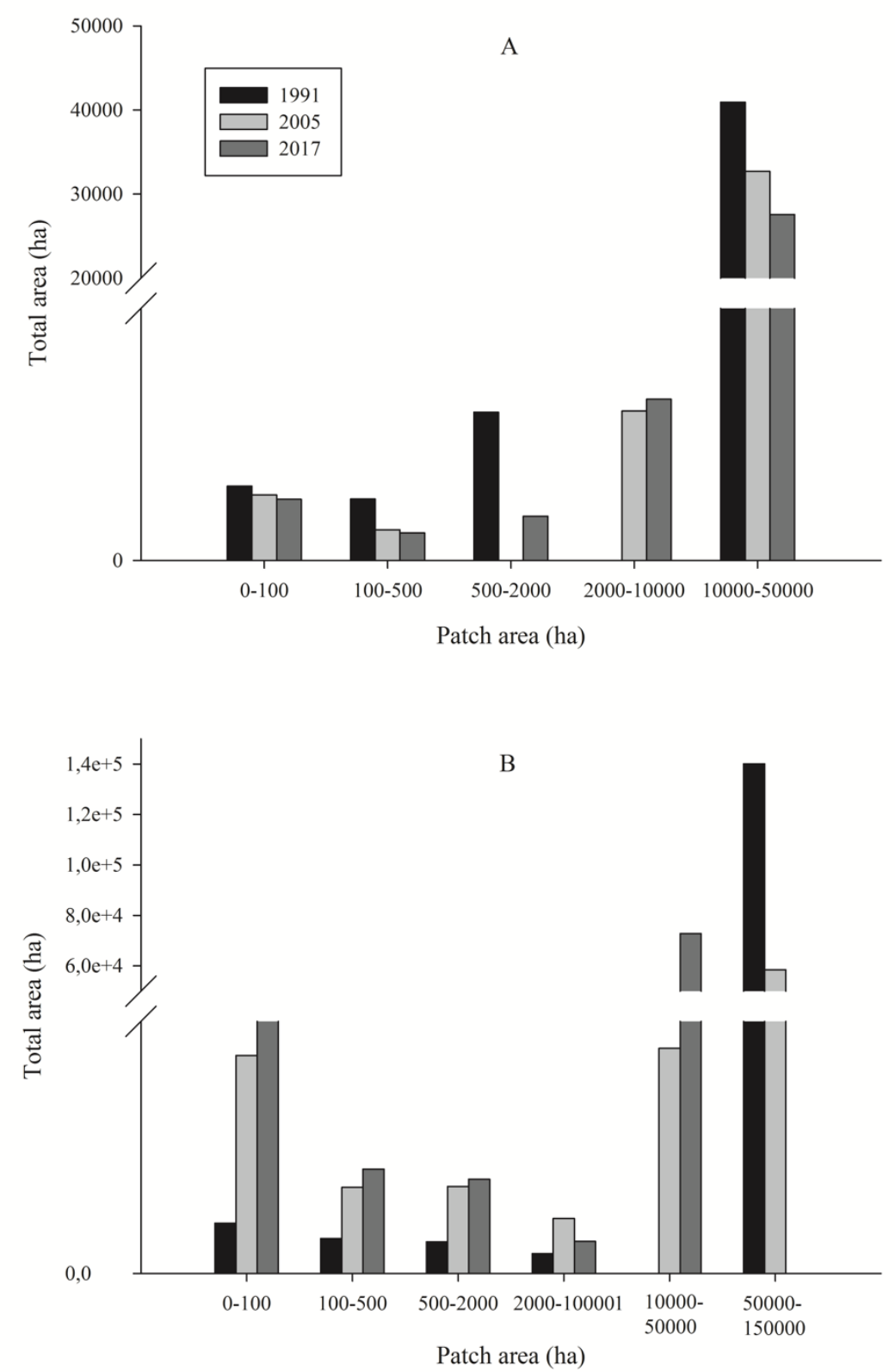
In 1991, $89 \%$ of the Tropical Montane Forest area was concentrated in patches between 50,000 and 150,000 ha; $4 \%$ in patches between 500 and 10,000 ha; and $7 \%$ of the remaining forest area occurred in patches of less than 500 ha (Fig. 4). In 2005, $42 \%$ of the Tropical Montane Forest area was concentrated in patches between 50,000 and 150,000 ha; $19 \%$ in patches between 10,000 and 50,000 ha; $10 \%$ in patches between 500 and 10,000 ha; and $28 \%$ of the remaining forest area occurred in isolated patches of less than 500 ha. In 2017, $56 \%$ of the Tropical Montane Forest area occurred in patches between 10,000 and 50,000 ha; $12 \%$ in patches between 500 and 10,000 ha; and $32 \%$ of the remaining forest area occurred in isolated patches of less than 500 ha (Fig. 4).

The largest forest patch of Inter-Andean Dry Forest and Tropical Montane Forest decreased by $1.95 \%$ and $16.33 \%$, respectively, from 1991 to 2017 (Table 3). The core area of the Inter-Andean Dry Forest and Tropical Montane Forest decreased by 0.10 and 0.29 , respectively, over the entire study period (Table 3). A decrease in the aggregation index between forest patches was observed. The largest decrease in the aggregation index occurred from 1991 to 2005, which was 3.09 \% and 8.51 \% for Inter-Andean Dry Forest and Tropical Montane Forest, respectively. From 1991 to 2005, an increase in the shape complexity of the Inter-Andean Dry Forest and Tropical Montane Forest patches was observed (Table 3). However, from 2005 to 2017 a decreased in this index was registered for both ecosystems. The degree of edge contrast between the forests and agriculture, which was the dominant cover in the landscape, increased by $32.6 \%$ and $31.5 \%$ for Inter-Andean Dry Forest and Tropical Montane Forest, respectively. The largest increase in the degree of edge contrast occurred from 1991 to 2005 . In the first study period, the total edge length increased by $1,637 \mathrm{~km}$ and $14,443 \mathrm{~km}$ for Inter-Andean Dry Forest and Tropical Montane Forest, respectively. In the second study period, a decreased in this index was registered for both ecosystems. The distance between patches of Inter-Andean Dry Forest and Tropical Montane Forest increased by $156 \mathrm{~m}$ and $68 \mathrm{~m}$, respectively, over the entire study period (Table 3). The largest increase in the distance between forest patches occurred from 1991 to 2005, which was $118 \mathrm{~km}$ and $63 \mathrm{~km}$ for Inter-Andean Dry Forest and Tropical Montane Forest, respectively (Table 3).

\section{DISCUSSION}

\section{Deforestation and fragmentation patterns}

This study revealed an important increase in agriculture and urban land-use between 1991 and 2017. The urban land-use was that registered a higher increase mainly due to the conversion of shrub vegetation to urban areas. While the conversion of forest lands to agriculture was the one that generated the greatest impact on Inter-Andean Dry Forest and Tropical Montane Forest. The largest loss of native forests occurred from 1991 to 2005 . The annual loss rate of forests reported in this study (1.0\% per year) is higher than that recorded in other hotspot landscapes that have also been significantly transformed, such as the Valdivian Temperate Forest in Chile ( $0.5 \%$ per year) (Rodríguez-Echeverry et al., 2018a) and the hotspot of the Eastern Arc Mountains of Tanzania $(0.5 \%$ per year) (Green et al., 2013). Similar to other countries, the deforested areas in the Ecuadorian Andes are mainly used for agriculture.

Specifically, our study registered an important rate of deforestation for Inter-Andean Dry Forest (1.3\% per year) and Tropical Montane Forest (0.7\% per year) between 1991 and 2017. In the provinces of Loja and Zamora Chinchipe in Ecuador, a similar annual deforestation rate in the Inter-Andean Dry Forest (1.2\% per year), and an annual deforestation rate higher for Tropical Montane Forest (6\% per year) were registered 
Rodríguez-Echeverry J., Leiton M.: State of the landscape and dynamics of loss and fragmentation of forest critically endangered in the tropical andes hotspot: Implications for conservation planning

(Tapia-Armijos et al., 2015). Forest loss in the Ecuadorian Andes is close to $80 \%$ due to the conversion of this ecosystem to agriculture (Ferrer-Paris et al., 2018). In the study landscape, forest deforestation is commonly characterized by its conversion to agriculture and is mainly concentrated in the valleys and lower slopes where it is more accessible to use the land. With an expanding population, production pressures have driven a rapid expansion of agriculture into forested areas (Sierra, 2013). The lack of effective conservation planning has inadequately exposed an area of high diversity and endemism to high rates of forest deforestation and fragmentation. Accordingly, urgent long-term conservation actions are needed in this landscape.

The loss of native forest area was associated with an increase in the number of patches during the first study period and a decrease in the subsequent study period. This trend is similar to that reported in other hotspot landscapes that have been significantly transformed, such as the Chilean Temperate Forest in the Nahuelbuta Mountain between 1986 and 2011 (Otavo \& Echeverría, 2017) and in the Chilean winter rainfall-Valdivian forests between 1970 and 2010 (Miranda et al., 2017). Our results show that the HRGW is a highly fragmented forest landscape. However, it is important to highlight that over the entire study period, and between 1991 and 2005, the main process that modified the Inter-Andean Dry Forest and Tropical Montane Forest was deforestation. The deforestation and fragmentation hotspots in the HRGW are located in areas where land is accessible, which is similar to that reported in the Colombian Andes (Rodríguez et al., 2013). If the current trajectory of loss and fragmentation of Inter-Andean Dry Forest and Tropical Montane Forest continues, further losses of both ecosystems can be expected.

\section{State of the landscape}

In 2017, the landscape registered a high rate of deforestation, a decrease in the number of forest patches, an increase in the distance between forest patches, a decrease in patch edges, and an increase in the matrix dominated by agriculture. Our results show that the landscape studied corresponds to an advanced state of a transformed landscape (McIntyre \& Hobbs, 1999; Echeverría et al., 2012). In this state, the loss of forest patches predominates over the division of them. Moreover, forest loss usually occurs after intense processes of forest fragmentation (McIntyre \& Hobbs, 1999; Echeverría et al., 2012). The state of the landscape studied is more critical than that observed in India between 1975 and 2005 (Reddy et al., 2013); and in southern Ecuador, between 1976 and 2008 (Sierra et al., 2013), where the reduction of large patches of native forest, and an increase in the number of patches occurred.

\section{Changes in the spatial pattern of forest cover}

The changes in the number of patches and total edge length were associated with deforestation. These metrics increased in the earliest stage of forest loss and fragmentation and decreased during the later stages of deforestation. Echeverría et al. (2006), also observed that the constant action of deforestation led to a decline in the number of patches and total edge length in central Chile. The decrease of edge length indicates that forest patches on average became less geometrically complex over time. Habitat patch shape has a strong effect on the presence of species, with fewer species in less geometrically complex patches (Haddad et al., 2015). In the study landscape, the patches of Inter-Andean Dry Forest and Tropical Montane Forest are less geometrically complex and sparsely distributed across the landscape, which can affect organisms with low mobility (McIntyre \& Hobbs, 1999).

In our study, patch size declined over time, which differs substantially from the situation recorded for the scrubby forest in the Nahuelbuta Mountain (Otavo \& Echeverría, 2017). Haddad et al. (2015), stated that progressive reduction in the size of forest habitats is a key 
component of ecosystem fragmentation. Therefore, the size reduction of forest patches in landscapes with high conservation priority may affect the availability of forest habitats (Moreno et al., 2014). In addition, several studies carried out in different forest ecosystems have shown that progressive reduction in the size of forest patches alters the structure of the forest habitat (Torrella et al., 2013; Rodríguez-Echeverry et al., 2015). Consequently, as the structural diversity of the forest decreases, the use of the habitat also decreases, which can produce a severe fragmentation and decline of the endangered populations (Lindenmayer \& Fischer, 2006).

High-contrast edges between Inter-Andean Dry Forest and Tropical Montane Forest with the agriculture were recorded in the landscape studied. Previous studies have also reported that monocultures may exhibit high-contrast edges with the natural habitat due to a more simple composition and structure (Reino et al., 2009; Echeverría et al., 2013). The edges play critical roles in the ability of species to adapt and move between disturbed habitats and in the introduction of edge effects that cause a deterioration in the qualities of habitats (Peyras et al., 2013). Therefore, a marked contrast between native forest ecosystems and human-related land can increase the risk of extinction for endangered species (Laurance et al., 2002; Peyras et al., 2013; Torrella et al., 2013). In the study landscape, the trajectories of non-forest cover changes were useful to explain the changes in the forest cover since the 1990s. While agriculture and urban areas cover increased, Inter-Andean Dry Forest and Tropical Montane Forest became gradually more fragmented and decreased their aggregation.

The results of the edge contrast metric were derived from field measurements, which were spatially analyzed by using remote sensors. The analysis of edge contrast in different spatial scales has been highlighted as a very important factor in detecting edge influence (Granados et al., 2014). Therefore, the edge contrast metric can be used to analyze the impact of human-induced land-use change on the spatial pattern of the forest landscape and thus to propose general guidelines for management and restoration in fragmented forest landscapes (Sano et al., 2009). This recommendation can contribute to recovering ecological integrity, especially in landscapes where the amount, size, and spatial configuration of suitable forest habitats are determinant for edge-sensitive species.

We observed that the highest loss of forest cover was associated with the highest loss of core areas over the entire study period. The reduction trend in the core area reported in this study is similar to that observed in native forests of other landscapes that are also areas of high priority for world conservation (Miranda et al., 2017; Otavo \& Echeverría, 2017). The core areas provide the optimal biotic and abiotic conditions to maintain biodiversity and ecological processes (Isaac-Cubides \& Ariza, 2016). Therefore, as the forest patches are smaller, the contribution of their core area will be less, as well as the integrity of the cover. If the loss of forest cover continues in the studied landscape, further losses of core area can be expected, which could impact the biodiversity and ecological processes of both ecosystems.

The landscape studied has been affected over the last 26 years by progressive isolation of the forest patches due to a significant reduction of forest cover by conversion to agriculture and urban areas. The main change in the average distance to the nearest neighbor was recorded between 1991 and 2005. During this period, the neighborhood of forest patches rapidly became occupied by areas of a different land cover type, as native forest patches became spatially separated and less contiguous in distribution. Some researchers have stated that the disruption of landscape connectivity may have important consequences for the distribution and persistence of population, and therefore with the maintenance of species diversity (Bennet, 2003; Pacioni et al., 2015; Thompson et al., 2017). Also, the disruption of landscape connectivity may lead to an increased risk of local extinctions, making species 
more vulnerable to stochastic processes, natural catastrophes, human threats, and loss of genetic variation (Paviolo et al., 2016; Horváth et al., 2019; Clerici et al., 2020). According to the findings in this study, a discontinuous spatial pattern of forest patches indicates low functional connectivity of the Inter-Andean Dry Forest and Tropical Montane Forest. This low functional connectivity can affect to move of organisms between habitat patches, the colonization of species, and gene exchange between populations (Echeverría et al., 2014). Therefore, the guidelines for management and conservation for both native forest ecosystems should consider the implementation of corridors to reduce the negative effects of fragmentation.

\section{Implications for conservation}

The HRGW should be considered as a premium conservation landscape, as it still concentrates high levels of biodiversity and endemism, and is simultaneously in an advanced state of landscape transformation. This premium condition justifies the urgency of safeguarding the Inter-Andean Dry Forest and Tropical Montane Forest whose risk of extinction may increase if the current trajectory of loss and fragmentation continues. We suggest carrying out conservation planning at a landscape scale based on the corridor-patch-matrix model. This model is an alternative to reduce and avoid the degradation of ecosystems, contributes to biodiversity conservation, and guarantees the participation of the Government and the community (Rodríguez-Echeverry \& Leiton, 2019).

The corridor-patch-matrix model is appropriate given the current configuration of the landscape of the HRGW, with Inter-Andean Dry Forest and Tropical Montane Forest restricted to small patches sparsely distributed across the landscape. The main objective of the corridor-patch-matrix model is to maintain the quality and quantity of the forest patches through the management of the matrix. Therefore, the management of the matrix should focus on the sensitive buffer areas that improve the connectivity between forest patches and increase the ability of the matrix to maintain biodiversity (Lindenmayer \& Fischer, 2006). Consequently, the management of the matrix should include the restoration of the Inter-Andean Dry Forest and Tropical Montane Forest on the sensitive buffer areas, which in turn would improve the connectivity of this ecosystem and increase the availability of habitats for species, such as S. guentheri, C. obsoletum, L. triangulum micropholis, A. geoffroyi, $R$. colomaromani, D. lafresnayii, among others. The management of the matrix should also include the implementation of sustainable production practices, such as agroforestry on the sensitive buffer areas. These practices could reduce the edge contrast and, thus, lowers the impacts to the patches of Inter-Andean Dry Forest and Tropical Montane Forest. The design and implementation of this strategy require the evaluation and identification of the sensitive buffer areas and their connectivity. Furthermore, this strategy must be complemented with land use planning and supported within a framework of environmental policies that guarantee the commitment and active participation of the Ecuadorian Government and the community in general. Finally, we suggested that future studies address the causes of the loss of Inter-Andean Dry Forest and Tropical Montane Forest and landscape transformation of the HRGW.

\section{CONCLUSIONS}

Our study constitutes the first analysis carried out on the spatio-temporal changes of the Inter-Andean Dry Forest and Montane Tropical Forest, in the HRGW, due to the intensification of agricultural and urban land-use. Accordingly, our study contributes to 
a better understanding of the impacts of increased agriculture and urban areas on these native ecosystems. Our results demonstrated that Inter-Andean Dry Forest and Tropical Montane Forest loss were largely caused by the conversion of forest lands to agriculture. In addition, the loss of both native ecosystems was related to its fragmentation during the first study period. Both ecosystems registered a similar trend of deforestation and fragmentation over the entire study period. According to our findings, urgent conservation efforts are required for the Inter-Andean Dry Forest and Tropical Montane Forest, in order to maintain high levels of biodiversity and endemism, and the provision of the ecosystem services.

The HRGW should be considered as a premium conservation landscape. Based on our findings, we suggest the patch-corridor-matrix model as a strategy for conservation planning of the Dry Inter-Andean Forest and Montane Tropical Forest on a landscape scale. This model is important because allowing maintaining the production lands. At small spatial scales, management decisions should be focused on particular plots of land, be they for commodity production or otherwise. But at landscape-scales, conservation decisions should be focused on the choice between mosaics with contrasting patches of production and conservation lands. In this way, socio-economic development can be in concordance with conservation. Therefore, the patch-corridor-matrix model can ensure the provision of multiple ecosystem services that would provide human well-being to the inhabitants of the HRGW. Furthermore, this model must be supported by a framework of environmental policies, which must be based on the $17 \mathrm{UN}$ sustainability criteria and generated by the Ecuadorian government. We want to emphasize that the successful conservation of both ecosystems requires the engagement of multidisciplinary teams and related stakeholders.

\section{ACKNOWLEDGEMENTS}

We thank the project "Planning for the environmental sustainability of the territory of the Rio Guayllabamba watershed, Ecuador", within which this study was conducted. We also thank to Ing. Albert Hernández for his revision and the comments received from the anonymous reviewers.

\section{CONFLICTS OF INTEREST}

The authors declare no conflict of interest.

\section{REFERENCES}

Aguirre, Z., Kvist, L.P., Sánchez, O., (2006). Bosques secos en Ecuador y su diversidad. In M. Moraes, B. Ollgaard, L.P. Kvist, F. Borchsenius, Balslev, H. (Eds.). Botánica Económica de los Andes Centrales La Paz Bolivia: Universidad Mayor de San Andrés (pp. 162-187).

Aguirre, Z., Román, J.L., Montalvo, D., Cevallos, G., Albuja, L., Arguero, A., ... Carvajal, V., (2011). Biodiversidad de los valles secos interandinos del Ecuador. Ecuaoffset, Escuela Politécnica Nacional,Quito-Ecuador.

Bennett, A.F., (2003). Linkages in the landscape: the role of corridors and connectivity in wildlife conservation. IUCN Gland: Switzerland and Cambridge. UK.

Cadena-Ortíz, H., Varela, S., Bahamonde-Vinueza, D., Freile, J.F., Bonaccorso, D., (2015). Birds of Bosque Protector Jerusalem, Guayllabamba Valley, Ecuador. Check List. 11(5), 1770. https://doi.org/10.15560/11.5.1770. 
Rodríguez-Echeverry J., Leiton M.: State of the landscape and dynamics of loss and fragmentation of forest critically endangered in the tropical andes hotspot: Implications for conservation planning

Chander, G., Markham, B.L., Helder, D.L., (2009). Summary of current radiometric calibration coefficients for Landsat MSS, TM, ETM+, and EO-1 ALI sensors. Remote Sensing of Environment. 113, 893-903. https://doi.org/10.1016/j.rse.2009.01.007.

Cisneros-Heredia, D.F., Almendáriz, A., Yánez-Muñoz, M., (2017). Dipsas elegans. The IUCN Red List of Threatened Species. Retrieved April 28, 2020, from http://dx.doi.org/10.2305/IUCN.UK.2017-2.RLTS. T50951285A50951294.en.

Clerici, N., Armenteras, D., Kareiva, P., Botero, R., Ramírez-Delgado, J.P., Forero-Medina, G., ... Biggs, D., (2020). Deforestation in Colombian protected areas increased during post-conflict periods. Nature. 10, 4971. https://doi.org/10.1038/s41598-020-61861-y.

Daly, C. (2006). Guidelines for assessing the suitability of spatial climate data sets. International Journal of Climatology. 26, 707-721. https://doi.org/10.1002/joc.1322.

Echeverría, C., Coomes, D., Salas, J., Rey-Benayas, J. M., Lara, A., Newton, A., (2006). Rapid deforestation, and fragmentation of Chilean temperate forests. Biological Conservation. 130, 481- 494. http://doi.org/10.1016/j.biocon.2006.01.017.

Echeverría, C., Newton, A., Nahuelhual, L., Coomes, D., Rey-Benayas, J.M., (2012). How landscapes change: integration of spatial patterns and human processes in temperate landscapes of southern Chile. Applied Geography. 32, 822-831. https://doi.org/10.1016/j.apgeog.2011.08.014.

Echeverría, C., Gatica, P., Fuentes, R., (2013). Habitat Edge Contrast as an Indicator to Prioritize Sites for Ecological Restoration at the Landscape Scale. Naturez \& Conservação. 11(2), 170-175. http://dx.doi.org/10.4322/natcon.2013.026.

Echeverría, C., Bolados, G., Rodríguez, J., Aguayo, M., Premoli, A., (2014). Ecología de paisajes forestales. In C. Donoso, M.E. González, Lara A. (Eds.). Ecología forestal. Bases para el manejo sustentable y conservación de los bosques nativos de Chile. Santiago de Chile: Ediciones UACh, pp. 583-604.

ESRI, (2016). Environmental Systems Research Institute, Inc. In: 380 New York St., Redlands (pp. 220-225), CA92373-8100, USA.

Ferrer-Paris, J.R., Zager, I., Keith, D.A., Oliveira-Miranda, M.A., Rodríguez, J.P., Josse, C., ... Barrow, E., (2018). An ecosystem risk assessment of temperate and tropical forests of the Americas with an outlook on future conservation strategies. Conservation Letters. E12623, 1-10. https://DOI: 10.1111/conl.12623.

Foody, G.M., (2002). Statusof land cover classification accuracy assessment. Remote Sensing of Environment. 80, 185-201.

Granados, C., Serrano, D., García-Romero, A., (2014). Efecto de borde en la composición y en la estructura de los Bosques Templados, Sierra de Monte-Alto, Centro de México. Caldasia. 36(2), 269-287. http://dx.doi.org/10.15446/caldasia/v36n2.47486.

Green, J.M., Larrosa, C., Burgess, N.D., Balmford, A., Johnston, A., Mbilinyi, B.P., ... Coad, L., (2013). Deforestation in an African biodiversity hotspot: extent, variation, and the effectiveness of protected areas. Biological Conservation. 64, 62-72. https://doi.org/10.1016/j.biocon.2013.04.016

Haddad, N.M., Brudvig, L.A., Clobert, J., Davies, K.F., Gonzalez, A., Holt, R.D., ... Townshend, J., (2015). Fragmentation and its lasting impact on Earth's ecosystems. Applied Ecology. 1, 1-9. DOI: 10.1126 / sciadv.1500052.

Horváth, Z., Ptacnik, R., Vad, C.F., Chase, J.M., (2019). Habitat loss over six decades accelerates regional and local biodiversity loss via changing landscape connectance. 
Ecological Letters. 22, 1019-1027. doi: 10.1111/ele.13260.

Huete, A.R., (1988). A soil-adjusted vegetation index (SAVI). Remote Sensing of Environment. 25, 295-309.

IDRISI., (2012). Selva help system. Clark University: Clark Labs, USA.

Instituto Nacional de Meteorología e Hidrología., (2005). Estudio Hidrológico del Río Mira. Estudios e Investigaciones Hidrológicas. Quito-Ecuador: INAMHI.

Isaac-Cubides, P., Ariza, A., (2016). Monitoreo a la restauración ecológica desde la escala del paisaje. In: M. Aguilar-Garavito, Ramírez W. (Eds.), Monitero a procesos de restauración ecológica aplicado a ecosistemas terrestres (pp. 51-66). Bogotá Colombia: Instituto de Investigación de Recursos Biológicos Alexander von Humboldt.

IUCN. (2000). Tropical Montane Cloud Forest. WWF International/IUCN, Switzerland.

Laurance, W. F., Lovejoy, T. E., Vasconcelos, H. L., Bruna, E. M., Didham, R. K., Stouffer, P.C., ... Sampaio, E. (2002). Ecosystem decay of Amazonian forest fragments: a 22 -year investigation. Conservation Biological. $\quad$ 605-618. https://doi.org/10.1046/j.1523-1739.2002.01025.x

Lindenmayer, D., Franklin, J., (2002). Conserving forest biodiversity: a comprehensive multiscaled approach. Island Press, Washington.

Lindenmayer, D., Fischer, J., (2006). Habitat fragmentation and landscape change: an ecological and conservation synthesis. Island Press, Washington.

Lindenmayer, D., (2016). Interactions between forest resource management and landscape structure. Current Landscape Ecology Report. 1, 10-18. DOI 10.1007/s40823-016-0002-0.

López-Barrera, F., (2004). Estructura y función en bordes de bosques. Revista Ecosistemas, $13,55-68$.

McGarigal, K., Cushman, S., Neel, M., Ene, E., (2013). FRAGSTATS. Spatial pattern analysis program for categorical maps. University of Massachusetts, Amherst. (Landscape Ecology Program). Retrieved September 30, 2019, from http://www.umass.edu/landeco/research/fragstats/fragstats.html.

McIntyre, S., Hobbs, R., (1999). A framework for conceptualizing human effects on landscapes and its relevance to management and research models. Conservation Biological. $13,1282-1292$.

MECN., (2009). Ecosistemas del Distrito Metropolitano de Quito (DMQ). Ambiental del MDMQ, Quito-Ecuador.

Ministerio del Ambiente del Ecuador., (2013). Sistema de Clasificación de los Ecosistemas del Ecuador Continental. Subsecretaría de Patrimonio Natural, Ministerio del Ambiente, Quito-Ecuador.

Miranda, A., Altamirano, A., Cayuela, L., Lara, A., Gonzalez, M., (2017). Native forest loss in the Chilean biodiversity hotspot: revealing the evidence. Regional Environmental Chang, 17, 285-297. DOI 10.1007/s10113-016-1010-7.

Mittermeier, R.A., Turner, W.R., Larsen, F.W., Brooks, T.M., Gascon, C., (2011). Global biodiversity conservation: the critical role of hotspots. In F.E. Zachos, Habel, J.C. (Eds.), Biodiversity hotspots: distribution and protection of conservation priority areas (pp. 3-23). Berlin: Springer.

Moreno, R.A., Zamora, R., Herrera, M.A., (2014). Habitat selection of endemic birds in temperate forests in a biodiversity "Hotspot". Forest Systems. 23, 216-224.DOI:10.5424/fs/ 2014232-03700. 
Rodríguez-Echeverry J., Leiton M.: State of the landscape and dynamics of loss and fragmentation of forest critically endangered in the tropical andes hotspot: Implications for conservation planning

Myers, N., Mittermeier, R.A., Mittermeier, C.G., Da Fonseca, G.A.B., Kent, J., (2000). Biodiversity hotspots for conservation priorities. Nature. 403, 853-858.

NatureServe \& EcoDecision., (2015). Hotspot de Biodiversidad de los Andes Tropicales. Argentina, Bolivia, Chile, Colombia, Ecuador, Perú, Estados Unidos and Venezuela: Partnership Fund Critical Ecosystem.

Newton, A.C., (2007). Biodiversity loss and conservation in fragmented forest landscapes: the forests of montane Mexico and temperate South America. Wallingford, Oxford: CABI.

Otavo, S., Echeverría, C., (2017). Fragmentación progresiva y pérdida de hábitat de bosques naturales en uno de los hotspot mundiales de biodiversidad. Revista Mexicana de Biodiversidad. 88, 924-935. Doi:org/10.1016/j.rmb.2017.10.041.

Pacioni, C., Hunt, H., Allentoft, M.E., Vaughan, T.G., Wayne, A.F., Baynes, A. (2015). Genetic diversity loss in a biodiversity hotspot: ancient DNA quantifies genetic decline and former connectivity in a critically endangered marsupial. Molecular Ecology. 24, 5813-5828. doi: $10.1111 / \mathrm{mec} .13430$.

Paviolo, A., DeAngelo, C., Ferraz, K., Morato, R.G., Pardo, J.M., Srbek-Araujo, A.C., (2016). A biodiversity hotspot losing its top predator: The challenge of jaguar conservation in the Atlantic Forest of South America. Nature. 6, 1-16. DOI: 10.1038/srep37147.

Peng, J., Wang, Y., Zhang, Y., Wu, J., Li, W., Li, Y., (2010). Evaluating the effectiveness of landscape metrics in quantifying spatial patterns. Ecological Indicators. 10, 217-223. Doi:org/10.1016/j.ecolind.2009.04.017.

Peyras, M., Vespa, N.I., Bellocq, M.I., Zurita, G.A., (2013). Quantifying edge effects: the role of habitat contrast and species specialization. Journal of Insect Conservation. 17, 807-820. https://DOI 10.1007/s10841-013-9563-y.

Reddy, C.S., Sreelekshmi, S., Jha, C., Dadhwal, V., (2013). National assessment of forest fragmentation in India: landscape indices as measures of the effects of fragmentation and forest cover change. Ecological Engineering. 60, 453-464. Doi:org/10.1016/j.ecoleng. 2013.09.064.

Reese, H., Olsson, H., (2011). C-correction of optical satellite data over alpine vegetation areas: a comparison of sampling strategies for determining the empirical c-parameter. Remote Sensing of Environment. 115, 1387-1400. Doi:org/10.1016/j.rse.2011.01.019.

Reino, L., Beja, P., Osborne, P.E., Morgado, R., Fabião, A., Rotenberry, J.T., (2009). Distance to edges, edge contrast and landscape fragmentation: interactions affecting farmland birds around forest plantations. Biological Conservation. 142, 824-838. Doi:org/10.1016/j.biocon.2008.12.011.

Rodríguez-Echeverry, J., Echeverría, C., Nahuelhual, L., (2015). Impacts of anthropogenic land-use change on populations of the Endangered Patagonian cypress Fitzroya cupressoides in southern Chile: implications for its conservation. Oryx. 49(3),447-452. DOI: https://doi.org/10.1017/S0030605314000945.

Rodríguez-Echeverry, J., Echeverría, C., Oyarzún, C., Morales, L., (2017). Spatial Congruence between Biodiversity and Ecosystem Services in an Anthropic Landscape in Southern Chile: Basis for Conservation Planning. Bosque. 38(3), 495-507. DOI: 10.4067/S0717-92002017000300007.

Rodríguez-Echeverry, J., Echeverría, C., Oyarzún, C., Morales, L., (2018a). Impact of land-use changeon biodiversity and ecosystem services in the Chilean temperate forests. Landscape Ecology. 3(3), 439-453. DOI 10.1007/s10980-018-0612-5. 
Rodríguez-Echeverry, J., Fuentes, R., Leiton, M., Jaque, E., (2018b). Changing Landscapes Forest: Implications for its Conservation. Environment and Natural Resource Research. 8(3), 44-54. Doi:org/10.5539/enrr.v8n3p44.

Rodríguez-Echeverry, J., Leiton, M., (2019). Conservation Planning in Anthropogenic Landscapes. Ecology and Conservation Science. 1(1), 555-552.

Rodríguez, N., Armenteras, D., Retana, J., (2013). Land use and land cover change in the Colombian Andes: dynamics and future scenarios. Journal of Land Use Science. 8(2), 154-174

Sano, M., Miyamoto, A., Furuya, N., Kogi, K., (2009). Using landscape metrics and topographic analysis to examine forest management in a mixed forest, Hokkaido, Japan: Guidelines for management interventions and evaluation of cover changes. Forest Ecology and Management. 257, 1208-1218. Doi.org/10.1016/j.foreco.2008.10.005.

Sarmiento, F., (1995). Human Impacts on the Cloud Forests of the Upper Guayllabamba River Basin, Ecuador, and Suggested Management Responses. In L.S. Hamilton, J.O. Juvik, Scatena, F.N. (Eds.), Tropical Montane Cloud Forest. Springer-Verlag, New York, pp. 284-295.

Sierra, R., (2013). Patrones y factores de deforestación en el Ecuador continental, 1990-2010. Conservación Internacional Ecuador y Forest Trends, Quito-Ecuador.

Sistema Nacional de Información., (2019). Mapa de cobertura y uso de la tierra. Retrieved May 21, 2020, from http://sni.gob.ec.

Tapia-Armijos, M.F., Homeier, J., Espinosa, C. I., Leuschner, C., de la Cruz, M., (2015). Deforestation and forest fragmentation in South Ecuador since the 1970s losing a hotspot of biodiversity. PloS One. 10(9), e0133701. Doi:10.1371/journal.pone.0133701.

Thompson, P.L., Rayfield, B., Gonzalez, A., (2017). Loss of habitat and connectivity erodes species diversity, ecosystem functioning, and stability in metacommunity networks. Ecography. 40, 98-108. Doi: 10.1111/ecog.02558.

Torrella, S.A., Ginzburg, R.G., Adámoli, J.M., Galetto, L., (2013). Changes in forest structure and tree recruitment in Argentinean Chaco: Effects of fragment size and landscape forest cover. Forest Ecology and Management. 307, 147-154. http://dx.doi.org/10.1016/ j.foreco.2013.07.016 